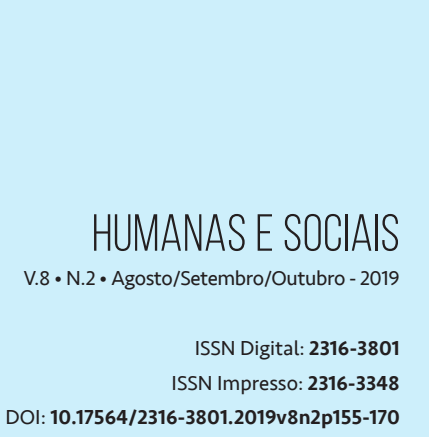

\section{O POLĹTICO NA HUMANIZAÇÃO DAS PENAS: UM OLHAR SOBRE O CASO TIRADENTES}

THE POLITICAL IN THE HUMANIZATION OF PENALTIES: A LOOK AT THE TIRADENTES ISSUE

EL POLITICIAN EN LA HUMANIZACION DE LAS PLUMAS: UNA MIRA EN EL CASODE TIRADENTES

Laís Mazzola Piletti ${ }^{1}$ Fernanda Cristina Covolan ${ }^{2}$

\section{RESUMO}

Este artigo tem por objetivo identificar o viés político na supressão do suplício como forma punitiva nos Códigos e práticas judiciais do Brasil republicano. Para tanto, utiliza a teoria foucaultiana acerca da redistribuição e reestruturação do exercício das práticas punitivas. Relaciona esse estudo do suplício à legislação penal e processual penal brasileira aplicada ao crime de lesa-majestade e às penalidades previstas para esse delito durante o Brasil colonial, especialmente no tocante ao caso Tiradentes. Analisa-se também a posterior reinterpretação do processo penal de Tiradentes com o advento da República, concomitante ao movimento de humanização das penas. Partindo da heroicização do alferes, pretende-se resgatar o sentido da reforma humanista em uma nova distribuição da economia de poder.

\section{PALAVRAS-CHAVE}

Caso Tiradentes. Economia de Poder. Humanização das penas. 


\section{ABSTRACT}

This article aims to identify the political bias in the suppression of torture as a punitive form in codes and judicial practices of republican Brazil. In order to accomplish this, it uses Foucault's theory of redistribution and restructuring of the exercise of punitive practices. It relates the study of torture to brazilian criminal and procedural criminal law applied to the crime of lese majesty and the penalties provided for such offense during the colonial Brazil, especially regarding the touching case of Tiradentes as a base. This writting also analyzes the subsequent reiterpretaton of the criminal proceedings in the instance of Tiradentes with the advent of the Republic, accompanying the movement of humanization of penalties. Starting from his heroization is intended to rescue the meaning of humanist reform in a new distribution in the economy of power.

\section{KEYWORDS}

Economy of Power. Humanization of Penaltie.Tiradentes Case.

\section{RESUMEN}

Este artículo tiene como objetivo identificar el sesgo político en la supresión del tormento como una forma punitiva en los códigos y prácticas judiciales del Brasil republicano. Para ello, utiliza la teoría foucaultiana sobre la redistribución y reestructuración del ejercicio de las prácticas punitivas. Se refiere a este estudio del tormento al derecho penal y al procedimiento penal brasileño aplicado al delito de lesa majestad y a las penas previstas para este delito durante el Brasil colonial, especialmente en relación con el caso Tiradentes. También analiza la posterior reinterpretación del proceso penal de Tiradentes con la llegada de la República, concomitante con el movimiento de humanización de las plumas. Partiendo de la heroicización del Alférez, se pretende rescatar la sensación de reforma humanista en una nueva distribución de la economía de poder.

\section{PALABRAS CLAVE}

Caso Tiradentes. Ahorro de energía. Humanización de las Plumas 


\section{INTRODUÇ̧̃̃o}

O presente trabalho parte do caso Tiradentes para identificar o elemento político na supressão do suplício como forma punitiva nos Códigos e práticas judiciais do Brasil republicano. Para tanto, utiliza a teoria foucaultiana acerca da redistribuição e reestruturação do exercício das práticas punitivas. Michel Foucault escreve uma história da justiça penal em que as transformações nas formas de punição são estudadas a partir de um investimento político sobre o corpo. Seu traçar de ideias comporta uma análise das penas cruéis que vigoraram no sistema judiciário ocidental até o século XIX. Naquela época, as penas se aplicavam de maneira pública, tendo caráter de ritual e espetáculo.

Relaciona esse estudo do suplício à legislação penal e processual brasileira aplicada ao crime de lesa-majestade e às penalidades previstas para esse delito. As Ordenações Filipinas, vigentes

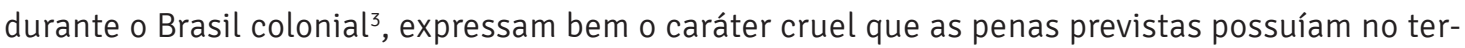
ritório pátrio. 0 exemplo mais famoso de aplicação desta lei pode ser encontrado no crime de lesa-majestade cometido por Tiradentes e outros inconfidentes. Assim, são abordados o processo e punição de Tiradentes; como seu corpo produziu uma verdade sobre o crime e foi utilizado para irradiar o poder do rei sobre a Inconfidência.

Analisa-se também a posterior reinterpretação do processo penal de Tiradentes com o advento da República. Posteriormente, foram modificados os sistemas punitivos e de controle social e a pena cruel sofrida pelo alferes foi usada para convertê-lo em herói pela República recentemente instaurada, mais de cem anos após sua morte. Simultaneamente, a prisão passa a ser a principal punição para a quase totalidade dos crimes. Partindo dessa heroicização, pretende-se resgatar o sentido da reforma humanista em uma nova distribuição da economia de poder.

\section{MICHEL FOUCAULT E AS PENAS CRUÉIS}

Até o final do século XVIII, imperava nas práticas punitivas ocidentais um estilo muito diverso do atual. Antes da publicidade dos processos e da humanização das penas, o corpo era o alvo primeiro da repressão penal. A morte e as penas físicas abrangiam uma parte considerável dos crimes nas legislações penais. Além disso, variavam em qualidade e intensidade de acordo com os crimes e status social dos criminosos. Essas características são analisadas por Michel Foucault em sua obra Vigiar e Punir e aqui expostas.

De acordo com Foucault (2013), a quantia de penas capitais aplicadas à época pode parecer imensa aos olhos contemporâneos, mas não deve ser ignorado o fato de que muitos juízes e tribunais co-

3 Acerca dos pormenores da vigência e aplicação das Ordenações Filipinas no Brasil, consultar o trabalho de Ricardo Marcelo Fonseca. Também de grande valia para quem busca compreender as pesquisas mais atuais sobre cultura jurídica, crime e sua punição no Brasil Colônia e Império, recomenda-se as pesquisas brilhantes que têm feito Luís Fernando Lopes Pereira, Danielle Wobetto de Araújo e Vanessa Massuchetto. 
mutavam as penas de morte para outras mais brandas. As condenações que mais ocorriam na prática penal francesa, por exemplo, eram de banimento ou multa. Entretanto, o aspecto quase onipresente era o suplício ${ }^{4}$. Independente da pena para o crime, quer nas execuções maiores em importância e publicidade, quer de forma acessória, o suplício era constatado.

Suplício é uma técnica. 0 sofrimento imposto por uma sentença judicial pode ser considerado desumano ou absurdo atualmente, mas nunca irregular ou irracional. Essa técnica punitiva é dotada de ao menos três critérios básicos: primeiramente, para ser considerada suplício, a pena deve causar um sofrimento que, de alguma forma, se equipare ao crime cometido. Os tipos de morte também variavam conforme a pessoa do criminoso e seu status social. Em segundo lugar, o suplício é um ritual. Há uma "liturgia punitiva" que marca a vítima e a torna infame, fazendo com que o povo guarde em sua memória as lembranças do crime e da violência que o seguiu (FOUCAULT, 2013, p. 35).

Por fim, o suplício deve também mostrar a força da justiça, que se impõe sobre o crime e o vence. A punição deve causar o sofrimento do condenado como demonstração do poder da lei. 0 sofrimento é ostentado ante a sociedade até depois da morte do supliciado: instrumentos de tortura deixados na praça, partes do corpo espalhadas no lugar onde foi cometido o crime, cinzas jogadas nos rios... "A justiça persegue o corpo para além de qualquer sofrimento possível” (FOUCAULT, 2013, p. 36).

Esta forma de produção de sofrimento, então, não pode ser comparada a qualquer outra: ele era produzido com respaldo legal e de modo a ser notado por todos. Não funcionava como uma justiça que, descontrolando-se, decidisse produzir uma vingança desmedida. Era, sim, todo o poder estatal investido no corpo do criminoso para que fosse constatada a supremacia do soberano.

\subsection{TORTURA NO INQUÉRITO}

Não é apenas no ritual punitivo que o corpo será supliciado. Antes de punir o corpo, o suplício o utilizava para descobrir a verdade sobre o crime. Diverso do que ocorre atualmente, o processo criminal era secreto, tanto para o povo quanto para o acusado. Somente a acusação possuía o direito ao saber: o acusado não podia ler as peças processuais, saber quem o tinha acusado nem conhecer o teor dos depoimentos das testemunhas. Do outro lado, o magistrado recebia denúncias anônimas e poderia interrogar o acusado através de enganos, mentiras e insinuações. A ciência do processo e o poder de decidi-lo pertenciam apenas ao soberano e juízes que partilhavam de seu poder (FOUCAULT, 2013, p. 37).

A investigação do crime visava obter a confissão. Michel Foucault (2013, p. 39) explicita os motivos: primeiro, ela era uma prova forte o suficiente para que mais nenhuma outra fosse necessária, o que facilita o trabalho do acusador. Não seria necessário obter outras provas. Além disso, ela representava uma vitória do poder sobre o acusado: este toma para si o crime e comprova o que foi obtido de forma velada pela investigação. 0 réu confesso aceita a acusação sem ele estabelecida e a torna uma informação própria, ligando-se ao rito que produz a verdade penal A confissão complementa o que está em falta na parte secreta e escrita do processo.

4 De acordo com Márcio Alves Fonseca (2005, p. 125), o suplício é uma pena física, que impõe ao corpo algum tipo de sofrimento por meio de inúmeras formas de violência, podendo ou não causar a morte. 
A grande importância da confissão explica então as duas formas que o direito usava para obtê-la: o juramento antes de interrogar o acusado e a tortura. Desrespeitar um juramento era tornar-se perjuro diante de Deus e dos homens. No direito penal clássico, a tortura não era vista como infamante, mas como um meio legal necessário para fazer com que o acusado pactuasse com a justiça e o poder punitivo. Depois da confissão obtida mediante tortura se fazia necessário que fosse repetida de forma "voluntária”. Dessa maneira, o interrogatório atuava mediante o suplício. Não para punir, mas para descobrir a verdade. 0 corpo supliciado devia trazer à luz o conhecimento do crime (FOUCAULT, 2013, p. 39).

\subsection{TORTURA COMO PENA}

No cumprimento da pena, o corpo é novamente usado de forma imprescindível. A justiça passa para o agora culpado do crime o papel de revelar sua culpa, condenação e verdade obtida pelo processo criminal. Seu corpo será encarregado de mostrar o que até então estava velado. 0 processo foi secreto, a pena deveria ser a mais pública possível.

Nas cerimônias do suplício, o personagem principal é o povo, cuja presença real e imediata é requerida para sua realização. Um suplício que tivesse sido conhecido, mas cujo desenrolar houvesse sido secreto, não teria sentido. Procurava-se dar o exemplo não só suscitando a consciência de que a menor infração corria sério risco de punição; mas provocando um efeito de terror pelo espetáculo do poder tripudiando sobre o culpado (FOUCAULT, 2013, p. 56).

Isso se mostrava, conforme explica Foucault (2013, p. 44-47), em quatro ângulos: Primeiramente, o culpado deveria ser o mensageiro de sua culpa e sentença. Andando pelas ruas com cartazes, confissões públicas, leitura reiterada de seu crime em vários pontos da cidade e também onde seria aplicada a pena. De alguma forma, ele traria a justiça para si.

Não bastasse, como num teatro, de forma pública o condenado confirmaria novamente seu crime e, se possível, estabeleceria uma verdade plena. Esses últimos instantes antes da execução da pena eram muito esperados: era comum que novos fatos sobre o crime aparecessem. Já que a pena seria aplicada de qualquer forma, confessar mais elementos do crime não traria prejuízo ao acusado. Dependendo do bom desempenho como ator, ele seria benquisto pelo povo.

Em terceiro lugar, relacionava-se o suplício ao tipo de crime cometido. A equivalência entre um e outro deveria ser percebida de forma bem clara. Assim, costumava-se deixar o corpo do condenado exposto no local de cometimento do crime, ou lembrava-se o tipo do crime pela forma de execução da pena. Havia arte na maneira como se supliciava.

Por fim, cada reação do condenado era observada para saber como seria julgada sua alma. Na tortura do inquérito, havia esperança de salvar o corpo da morte. Na tortura da punição, o que se visa salvar é a alma. Se o acusado mostrava arrependimento, se sua morte ocorreu em duas horas ou seis, se conservava a calma etc. Cada um desses aspectos dava um sinal de como a alma do supliciado seria recebida por Deus, se Ele o abandonou às mãos humanas ou demonstrou piedade o livrando de sofrimentos extremos.

0 que o supliciado sofre poderia purgar os pecados que cometeu. Se aceitasse e suportasse o martírio com dignidade, Deus se compadeceria. Os flagelos na Terra seriam capazes de diminuir a pena divina. Por outro lado, sofrimento exagerado poderia ser interpretado como um sinal do abandono 
de Deus, que não o impediu de cair em desespero. Esses paradoxos levavam as multidões a comprimirem-se para assistir as execuções. Estudavam o que se passava, tentando apreender o significado cada gesto, cada mínimo sinal.

“O suplício judiciário deve ser compreendido também como um ritual político” (FOUCAULT, 2013, p. 47). A principal função da punição cruel seria manifestar o poder, já que além de burlar uma regra o criminoso desrespeitava o direito que a constituía. 0 crime lesionava o monarca em um tempo em que este se fazia a lei. Na referência à lei o significado político do suplício é claro. Se torna uma mecânica do poder. É um ritual pedagógico, que reativa o poder do soberano e triunfa sobre aquilo que se lhe opôs (FONSECA, 2002, p. 128).

A punição, por conseguinte, não tencionava apenas reparar um dano e retirá-lo da sociedade: era uma espécie de resposta pessoal do rei ao crime. O suplício deve restaurar a soberania ferida, exibindo a força do soberano. Mostra a disparidade entre quem ousou lesar o Estado e a onipotência deste. Para mostrar a superioridade intrínseca do poder monárquico, a execução da pena muitas vezes ultrapassava em crueldade o crime (FOUCAULT, 2013, p. 47).

A réplica da autoridade consistia em castigar o corpo e expô-lo vencido, marcado e deformado. Era formada uma imagem de medo que dificilmente seria esquecida pelos cidadãos, tornando-os cientes de que a cólera do monarca sobrepujaria qualquer crime cometido. A festa punitiva não fazia a justiça, mas restabelecia o poder. Por essa razão a publicidade do processo: nada desse triunfo deveria ficar escondido (FOUCAULT, 2013. 49).

Tendo em vista o suplício como agente político, qualquer criminoso era um regicida em maior ou menor grau (FOUCAULT, 2013, p 43). O soberano, diretamente ou não, decide acerca de todos os castigos. Ele é atingido pelo crime através da lei.

O regicida, por sua vez, não é nem mais nem menos que o criminoso total e absoluto, pois em vez de atacar, como qualquer delinquente, uma decisão ou uma vontade particular do poder soberano, ele ataca seu princípio na pessoa física do príncipe (FOUCAULT, 2013, p. 53).

Por isso o crime diretamente contra o rei era considerado o pior dos delitos, pelo que a punição devia figurar como a mais cruel. Geralmente era uma combinação de todos os suplícios juntos, que ocorriam antes e depois da morte do condenado. Havia questões pormenorizadas quanto à liturgia da aplicação da pena. Quase sempre estava presente um aparato militar, que demonstrava a derrota dos inimigos e prevenia qualquer revolta popular. Reitera-se que a punição visava mais manifestar força que operar justiça.

Por essa razão, constata-se que o povo era, como expectador, peça principal desse espetáculo. De nada adiantaria uma liturgia com exército, teatro e crueldade se o povo não só tivesse conhecimento do que ocorrera, como visse com os próprios olhos. Até participava de forma ativa, sob a forma de agressões leves e ofensas (FOUCAULT, 2013, p. 50).

\section{A MITIGAÇÃO DAS PENAS}

O perigo das punições em forma de espetáculo residia nas situações em que o povo considerava a condenação injusta, buscando libertar das mãos dos carrascos os condenados (FOUCAULT, 2013, p. 59). Ou, como ocorria com frequência, nos suplícios em que o condenado, nada tendo a perder, maldizia leis, 
instituições, justiça e o próprio rei. O povo, nestes casos, sentia-se livre para unir-se ao supliciado nessas aclamações. Os papeis se invertiam, o poder era desprestigiado e o bandido aclamado como herói.

A crueldade do rei passa a ser objeto de revolta popular: este estava presente em muitas das punições e todas elas eram causadas pelo exercício de seu poder. Isso pode ser notado nas críticas de Beccaria (2005, p. 66) sobre a barbárie da tortura. Denunciava o fim político dos castigos, que era imprimir terror nos "corações inclinados ao crime".

Quem, ao ler na história, não se arrepia de horror com os bárbaros e inúteis tormentos, friamente concebidos e executados por homens que se diziam sábios? [...]. Vemos praticar sem repugnância e sem furor o assassínio, que nos é apontado como um crime hediondo (BECCARIA, 2005, p. 94).

Por suas características, o suplício passa a ser um exercício ilegítimo do poder. Ele suscita a revolta do povo, expressa a vergonha a que o condenado é submetido e representa um grande perigo: de tão acostumado a cenas sangrentas vindas do Estado, o povo aprende que a vingança contra os excessos cometidos pelo rei poderia se operar em forma de sangue (FONSECA, 2002, p. 128).

A maior fonte de desaprovação ao exercício da justiça penal era o poder excessivo dos juízes e outras pessoas relacionadas ao rei, mas principalmente ao poder do próprio soberano. Este mostrava ser um "superpoder": toda a dinâmica punitiva era controlada e exercida pelo monarca (FONSECA, 2002, p. 129).

A disfunção da justiça derivava da sua ligação essencial ao poder monárquico. Este se mostrava um "superpoder" quando relacionado às práticas legais, de maneira que o poder de punir era totalmente identificado ao poder pessoal do monarca (FONSECA, 2002, p. 129). O que está realmente em jogo no processo de reforma do Direito Penal na segunda metade do sec. XVIII era o estabelecimento de uma nova economia política do poder punitivo.

Ao estudar o investimento político sobre o corpo, é possível notar no movimento influenciado pelo pensamento iluminista de Beccaria a existência de elementos não jurídicos (DAL RI JUNIOR, 2002, p. 175). A humanização das penas "primitivas", que "evoluíram" e deram lugar a outras que respeitassem a dignidade humana, como discursa o direito oficial, tinha outras finalidades além da recuperação do delinquente. Não visa apenas equilibrar os delitos e as penas, mas redistribuir a economia de poder. Que o poder de punir não se enfeixe totalmente nas mãos de um rei. A reforma se traduz numa luta contra o poder ilimitado do soberano.

Após as reformas humanitárias, o poder que pune fica oculto. Torna-se necessário punir de outra forma. A confrontação física entre o soberano e o condenado precisa ser eliminada, assim como o confronto entre o carrasco e o supliciado, que não revelam nada mais que a vingança do príncipe e a cólera que o povo deve conter. "É preciso que a justiça penal puna ao invés de se vingar" (FOUCAULT, 2013, p. 72). Remaneja-se o poder de punir para que este seja mais detalhado, eficaz e constante em seus efeitos.

\section{TIRADENTES E AS ORDENAÇÕES FILIPINAS}

Como na França analisada por Foucault, o primeiro conjunto de normas penais e processuais penais a viger no Brasil ilustrava o mesmo modo de exercício de poder no corpo e sobre o corpo: as Or- 
denações Filipinas, livro V. A partir de 1603, essa ordenação cumpriu seu papel intimidador, refletindo o espírito penal que havia naquela época.

Além da morte, muitas penas infamantes eram previstas e a desproporção entre o delito e a pena se fazia notória. As Ordenações Filipinas tinham como característica principal o fato de fundamentar-se em um emaranhado e confuso mundo de regras severas que se pareciam com o crime, mas na maior parte dos casos não eram efetivamente aplicadas. Era um sistema que amedrontava para evitar castigar (SALGADO, 2008).

Conforme Hespanha (apud DAL RI JUNIOR, 2006), a justiça penal realmente praticada no Antigo Regime não era muito efetiva. Muitos malefícios poderiam ser pagos com dinheiro e nem o degredo possuía tanta efetividade, pois por vezes não era excessivamente prejudicial para o condenado. 0 rei, então, não era fonte de uma justiça cotidiana, mas sim dispensador de uma justiça cada vez mais teórica. Se fazia temer ameaçando e se fazia amar não cumprindo. Para que esse sistema funcionasse, era preciso manter a ameaça e conceder justiça ou misericórdia a partir da apreciação concreta e particular de cada caso.

O fato jurídico mais notório a ser regulado por esse Código Penal foi o Caso Tiradentes (DAL RI JUNIOR, 2006). Munidos de insatisfação contra a coroa portuguesa, que já durava anos, um grupo variado ${ }^{5}$, cuja maioria pertencia à elite, deu origem ao movimento separatista que ficou conhecido como Inconfidência Mineira. Pretendiam independência em relação a Portugal.

O plano não se efetivou, pois um dos membros do movimento traiu os demais, tendo em vista as vantagens que a delação premiada oferecia. 0 crime denunciado era o mais grave de todos, pois atacava diretamente a pessoa do rei. Estava expresso no título VI das Ordenações Filipinas como Crime de Lesa-Majestade. Era, segundo as próprias Ordenações

Traição còmettida contra a pessoa do Rey, ou seu Real Stado, que he tão grave e abominavel crime, e que os antigos Sabedores tanto estranharão, que o comparavão á lepra, porque assi como esta enfermidade enche todo corpo, sem nunca mais se poder curar, e empece e infama os que de sua linha descendem, posto que não tenhão culpa (PORTUGAL, 1603).

Comparar tal crime à lepra fazia com que, no imaginário popular, o criminoso acusado de traição ao Estado fosse concebido como um sujeito corrompido e degenerado, que merecia a segregação social (DAL RI JUNIOR, 2006, p. 146). Mais especificamente, os inconfidentes foram acusados de cometer o expresso nos parágrafos 5 e 6 do Título $\mathrm{VI}$, aqui transcritos:

O quinto, se algum fizesse conselho e confederação contra o Rey e seu Stado, ou tratasse de se levantar contra ele, ou para isso desse ajuda, conselho e favor (5). O sexto, se ao que fosse preso por qualquer dos sobreditos casos de traição, algum désse ajuda, ou ordenasse como de feito fugisse, ou fosse tirado da prisão (6) (PORTUGAL, 1603).

O crime de lesa-majestade era, teoricamente, punido com a morte natural cruel e o confisco de bens. Havia três tipos de pena capital: morte cruel, que continha suplícios e lentidão na execução;

5 Para compreender protagonistas, ações e projetos da Inconfidência é necessário considera-los mais num contexto de heterogeneidade social e econômica do que forte coesão ideológica em torno de um projeto bem definido. Sobre este assunto, recomenda-se a pesquisa de João Pinto Furtado (2001) 
morte atroz, caracterizada por esquartejamento ou queima de cadáver; e morte simples, comumente destinada à classe inferior por expressar infâmia. Além das penas de morte, as Ordenações Filipinas se valiam de penas corporais, como flagelações públicas e mutilações, penas de degredo e desterro, multas, confisco de bens e infâmia, que impedia o condenado de exercer funções públicas e podia se estender aos parentes deste (SALGADO, 2008).

Logo após a denúncia foi instaurado o inquérito, chamado Devassa, para que se descobrisse a verdade sobre o crime. As Ordenações não previam a instância judicial competente para julgar os crimes de lesa-majestade. Não há conhecimento de lei ou regimento que institua esses tribunais especiais. O nome "junta" permite supor não se tratar de um tribunal estável, mas de uma reunião ad hoc de autoridades que, habitualmente, tinham outras atribuições (DAL RI JUNIOR, 2006).

D. Maria I, a rainha, escreveu duas cartas régias para regulamentar todo o processo. Decidiu que o julgamento dos réus seria sumário, nomeou os magistrados do caso, declarou supridas quaisquer inobservâncias dos procedimentos processuais, estabeleceu o direito a ser aplicado e também como se operaria a gradação das penas e as hipóteses de perdão. Por meio dessas cartas, é possível entrever o poder jurisdicional absoluto que a monarca detinha e também o quanto sua pessoa estava envolvida em todo o processo $^{6}$ (TOSTO; LOPES, 2005).

Tiradentes foi interrogado onze vezes. Nas três primeiras inquirições negou os fatos. A partir da quarta, assumiu o crime, mas não delatou nenhum de seus companheiros. "Curioso notar que, neste depoimento, e nos que se seguiram, com raríssimas exceções, Tiradentes depôs 'livre de ferros'." (TOSTO; LOPES, 2005, p. 64). Os autores supracitados consideram "irônico" o que consta nos autos da devassa. Defendem ser ingênuo acreditar que, justamente no depoimento em que confessou sua culpa, Tiradentes não ter sido submetido à tortura? ${ }^{7}$.

Através da tortura, os inquisidores buscavam obter a mais relevante de todas as provas, a confissão, o que de fato conseguiram. As Ordenações Filipinas, no título 133 do livro V, previam a utilização de tormentos caso o juiz considerasse necessário, se houvesse fatos incriminadores suficientes para imputar ao réu a prática do crime. Na justificação de motivos pelos quais foi mantida a tortura, o Legislador afirmava que seria permitida somente nos casos das conjurações de muitos contra o Estado e a vida dos monarcas (PORTUGAL, 1603).

Se aceita a hipótese do suplício no processo investigatório, o corpo de Tiradentes produziu a verdade sobre o crime defendida pela autoridade, o que o tornava copartícipe de sua condenação. Após confessar, o destino de Tiradentes estava selado. De onze réus condenados à morte, apenas ele não teve a pena, por clemência da rainha, comutada em degredo. Além de ser o único a não ter influência na sociedade mineira ou ligações de família que o protegessem, Tiradentes assumiu a culpa quase que exclusiva da rebelião.

Ademais, sofreu a condenação porque o domínio do Império estava profundamente abalado. Um dos indícios seria o fato de que foi requerido ao vice-rei atribuir a investigação a algum outro crime,

6 A peça de defesa dos réus continha uma súplica à Rainha e um pedido de perdão, o que mais uma vez confirma o profundo envolvimento pessoal da soberana (SALGADO, 2008, p. 490).

7 Keneth Maxwel (1985, p. 299), menciona o cabeça do tribunal, Coutinho, que "intimidou, ameaçou, mortificou e contraditou os prisioneiros com horrenda efetividade". 
não o de traição, pois esta tipificação poderia colocar o povo a favor dos prisioneiros, tendo em vista a intensa impopularidade do governo, sobretudo por questões financeiras. Paradoxalmente, após a condenação a monarquia precisava de um espetáculo que infundisse terror e obediência ao povo (MAXWELL, 1985).

A leitura de uma carta de clemência da rainha, enviada ainda no início do processo para ser aberta somente depois do julgamento, mudou grandemente a consternação causada pela leitura das penas dos inconfidentes. Todas as sentenças, exceto a de Tiradentes, foram comutadas em banimento. A misericórdia da rainha fora distribuída, e o espetáculo estava quase no fim (MAXWELL, 1985). A sentença de Tiradentes dimensiona o quanto a punição caracteriza-se como retaliação real:

(...) com baraço e pregão, seja conduzido pelas ruas publicas dessa cidade ao lugar da forca, e nella morra morte natural para sempre, e que depois de morto the seja cortada a cabeça e levada a Villa Rica aonde no lugar mais público della será pregada, em um poste alto até que o tempo a consuma, e o seu corpo será dividido em quatro quartos, e pregados em postes pelo caminho de Minas no sitio da Varginha e das Sebolas aonde o réu teve as suas infames práticas e os mais nos sitios (sic)de maiores povoações até que o tempo também os consuma; declaram o réu infame, e seus filhos e netos tendo-os, e os seus bens applicam para o Fisco e a Câmara Real, e a casa em que vivia em Villa Rica será arrasada e salgada, para que nunca mais no chão se edifique e não sendo própria será avaliada e paga a seu dono pelos bens confiscados e no mesmo chão se levantará um padrão pelo qual se conserve em memória a infamia deste abominavel Réu (...)(Apud DAL RI JÚNIOR, 2006, p. 146).

No cumprimento da pena, o corpo de Tiradentes revelaria a soberania da rainha. Sua execução deu-se às 11 horas da manhã, para que o maior número de pessoas assistisse. Foi escoltado pela cavalaria real, um aparato militar que demostrou a força da rainha em dominar seus inimigos. Com baraço e pregão: o crime foi anunciado pela cidade. Foi enforcado; uma morte mais cruel que a decapitação, por exemplo.

De acordo com Arno Dal Ri Júnior (2006, p. 146),

São várias as semelhanças entre as execuções de Tiradentes e a de Damiens, o criminoso executado diante da catedral de Reims que se tornou célebre na narração oferecida por Michel Foucault nas primeiras páginas da obra 'Vigiar e Punir'. O esquartejamento em praça pública é realizado através de um macabro ritual em que o simbolismo penal defendido pelas teorias de prevenção/intimidação geral atinge o seu ponto máximo. Ao maior dos crimes, a maior e mais cruel das penas.

Conforme testemunha ocular anônima mencionada por José Murilo de Carvalho (1990, p. 58), a cidade nunca vira execução mais medonha e de mais feia ostentação, não conseguindo esconder a opressão que sentia. 0 confessor dos inconfidentes, Penaforte, afirma que no Rio de Janeiro muitas famílias retiraram-se para o campo, em contraposição ao povo que compareceu em grande número para assistir a execução. A razão para tal, segundo ele, foi “a compaixão do povo pela infelicidade temporal do réu, que para lhe apressarem a eterna ofereceram voluntariamente esmolas para dizerem missas por sua alma”. 
Após a morte, o suplício continua. Tiradentes teve seu corpo esquartejado e espalhado nos lugares em que havia sido cometido o crime, para que se estabelecesse a conexão com a pena. Cumpriu sua função intimidatória, mesmo que o corpo não tenha apodrecido até que se consumisse onde foi deixado, em lugares movimentados da capitania, como a sentença havia previsto (DAL RI JUNIOR, 2006). A infâmia do réu passou da sua pessoa para seus descendentes e sua memória e bens deveriam permanecer manchados.

Obviamente que a exibição da cabeça de Tiradentes causou uma profunda impressão na mente das pessoas em Minas Gerais. Documentos da época mencionam o sentimento de desolação que se espalhara por aquela capitania.

Ao visitar a província na metade do século XIX, Richard Burton anotou que se mantinha viva a memória dos acontecimentos e era corrente entre a população que a pena imposta aos inconfidentes fora excessiva e injusta (CARVALHO, 1990, p. 59).

Desta forma, em que pese a extensão da pena a que foi submetido Tiradentes, a parte final da sentença parece não ter sido alcançada. 0 esquecimento e a infâmia não foram tão profundos frente ao senso de injustiça que acompanhou sua memória.

\section{DE CRIMINOSO À MÁRTIR}

Depois de sua morte, Tiradentes foi esquecido por seus contemporâneos. O objetivo de sua pena era infamar a imagem do alferes pelo temor. Tal teria se concretizado muito além do mais de um século de esquecimento, não fosse a instauração da República: um vilão dentro de um regime pode ser considerado herói em outro. Como afirmou um dos inconfidentes, em seu interrogatório, "os Réus da Conjuração de Minas foram tratados como Rebeldes porque não conseguiram o seu fim, mas se 0 conseguissem seriam heróis" (MAXWELL, 1985, p. 281).

Conforme Dal Ri Junior (2006), o mito fundador da nacionalidade foi construído no imaginário brasileiro sobretudo a partir do martírio "foucaultiano" sofrido por Tiradentes. O processo de mitificação foi lentamente manipulado por ideólogos da "história oficial”, evocando um passado dignificante da nacionalidade brasileira. A República, cujo início se deu em 1889, precisava de símbolos para autoafirmar-se.

Heróis são símbolos poderosos, encarnações de idéias e aspirações, ponto de referência, fulcros de identificação coletiva. São por isso instrumentos eficazes para atingir a cabeça e o coração dos cidadãos a serviço da legitimação de regimes políticos (CARVALHO, 1990, p. 55).

No caso do Brasil, em que a construção da República teve pouca participação popular, tornou-se necessária uma compensação simbólica. Assim se construiu a figura do herói. Esse herói necessitava corresponder às características da população e refletir o comportamento que se esperava desta. Aos poucos, Tiradentes se revelou adequado à mitificação. Ele foi facilmente absorvido pela população pelas características messiânicas que the foram atribuídas.

A tranquila dignidade com que Tiradentes enfrentou a morte foi um dos poucos momentos heroicos do fracasso sombrio. Quase um século depois, quando o Brasil implantou a república, ele foi proclamado herói nacional (MAXWELL, 1985, p. 305). 
Constata-se que a forma como o corpo reage ao suplício é elemento preponderante para a formação de um herói. Sócrates, Jesus, Joana D’Arc, entre tantos outros, só o foram porque seu corpo reagiu de forma pacífica à pena cruel que lhes foi imposta. A maioria do povo era de tradição cristã e aceitou facilmente um mártir cuja coragem vinha "do fervor religioso e não do fervor cívico" (CARVALHO, 1990, 68).

Nada melhor que um homem do povo que houvesse sido supliciado por um ideal de independência. 0 império que oprimiu Tiradentes oprimia também o povo com seu aparato de terror e intimidação. Tiradentes foi, então, a figura escolhida pela República, pois representava um povo martirizado em sua busca por libertação.

\section{REFORMA PENAL NA REPÚBLICA}

Interessante notar que a República foi implantada em conjunto ao movimento pela humanização das penas. Pouco a pouco, as penas cruéis foram sendo retiradas dos dispositivos legais e substituídas por outras mais brandas. Durante o Império, houve algumas tentativas no sentido de abolir dispositivos de pena cruel. Mesmo assim, a punição ainda tinha o caráter de espetáculo e estava concentrada nas mãos do poder real.

Por várias razões, houve grande dificuldade em se implantar um sistema de penas mais humanitárias. Um dos fatores era a manutenção do vínculo do rei à aplicação das penas. Até a metade dos oitocentos, todas as penas de morte deveriam ser obrigatoriamente remetidas ao Imperador (DAL RI JUNIOR, 2012). O principal desses fatores, no entanto, era a situação particular do Brasil dos oitocentos, na qual as instituições modernas e liberais conviviam com a escravidão.

A escravidão se enquadrava nas duas categorias analisadas por Foucault, o suplício e a disciplina normalizadora. Combinava a ostentação da violência e a técnica de indução ao trabalho produtivo. Assim, a preocupação humanitária dos juristas, enquanto houve escravidão, era centrada nos homens livres. Isso gerava uma situação bastante contraditória no discurso liberal e moderno de modificação das penas ${ }^{8}$ (DAL RI JUNIOR, 2012).

Na organização do Brasil independente, a Constituição adotou os princípios da legalidade e da reponsabilidade individual pelos crimes, além de abolir as penas cruéis. Entretanto, na lógica disciplinar de uma sociedade escravista, a primeira preocupação estava em garantir a ordem social, e depois recuperar o criminoso. Assim, no Império, a lógica da reforma penal se traduzia em humanizar as penas dos homens livres e agravar as dos escravos ${ }^{9}$ (KOERNER, 2006).

Para o modo de produção que prevaleceu no Brasil do século XIX - escravismo interno, subordinado a relações internacionais capitalistas - a privação da liberdade (prisão simples) tinha uma função penal complementar e acessória. 0 controle social penal se exercia predominantemente através da pena de morte, de penas corporais (açoites) e de medidas que reproduziam a condição social escrava

8 Mario Sbriccoli (1974), além de abordar o crime de lesa-majestade em suas concepções oriundas do direito romano, reflete acerca desta noção de duplo nível de legalidade no Brasil dos séculos XIX e XX.

9 Com o tempo, a escravidão não é mais vista como legitimadora da manutenção da pena de morte. Pelo contrário, a pena de morte passa a deslegitimar a escravidão. Consultar Ribeiro (apud Dal Ri Jr, 2012, p. 159) 
(galés e prisão com trabalho). 0 escravo que não fosse condenado à morte ou às galés era necessariamente condenado à pena de açoites e imposição de ferros (art. 60 do Código Criminal do Império) (BATISTA, 1990, p. 124).

Por essas razões, Nilo Batista (1990) afirma que no final do século XIX o Brasil não tinha uma experiência penitenciaria avaliada. O desenvolvimento da burguesia na República ocorre juntamente ao da pena privativa de liberdade. A prisão celular, a reclusão e a prisão disciplinar foram previstas no artigo 43 do Código Penal de 1890. De um modo diferente do ocorrido na Europa, a fábrica e o cárcere se entrelaçaram no processo histórico brasileiro.

Foram desenvolvidas fábricas-prisões para os menores trabalharem (arts. 30 e 49 do Código, e dec. $n^{0} 1313$, de 17.jan. 1891), remoção de vadios e vagabundos para colônias penais e privação de liberdade para homens livres que cometessem crimes. Entre a fábrica e o cárcere, o sistema penal assumiu uma atuação rigorosa na República, eliminando a perspectiva de "clemência" ou "indulgência" que as penas possuíam quando associadas ao poder soberano do Império (BATISTA, 1990).

A prisão como forma punitiva no Brasil representa o estabelecimento de um novo sistema penal, em que o poder estatal não é mais diretamente responsabilizado pelos casos concretos. 0 poder reparte-se em várias microinstituições como prisão, polícia, médicos, juízes etc. A punição é tirada dos olhos do povo. Não se vê mais o Estado punindo ou utilizando o corpo do condenado para reafirmar seu poder e soberania. Lidar com o criminoso é uma parte vergonhosa do direito que o Estado procura ocultar. Utilizar-se de seu corpo como punição, então, é inconcebível (FONSECA, 2002).

Não era interessante uma pena secreta quando as execuções de sentença se faziam festas punitivas com o objetivo de impressionar a população expectadora. Inaugurado o novo sistema político, visava-se proteger a figura estatal. Redistribuiu-se a economia de poder e os espetáculos foram suprimidos, pertencendo à figura do Imperador (FONSECA, 2002).

Os festivais punitivos são relembrados pela República com a figura de Tiradentes. 0 alferes foi feito herói porque seu sofrimento traça para o povo a evolução que a República trouxe em relação ao império: os corpos não são mais supliciados, fica de lado a ferocidade penal. No herói do novo governo, é possível perceber a disparidade entre o já passado suplício e a proteção à integridade física e moral dos cidadãos, a proibição dos espetáculos punitivos e a preocupação com a dignidade dentro do sistema punitivo.

\section{CONSIDERAÇ̃̃ES FINAIS}

Esta pesquisa analisou a punição cruel de Tiradentes sob a abordagem de Michel Foucault e a posterior humanização das penas nas práticas penais republicanas, concomitante à heroicização do alferes. Com a análise desses fatos históricos, teve por objetivo compreender a supressão do suplício em seu viés político, que se traduz na redistribuição da economia de poder.

Os suplícios previstos no sistema penal do Império ligavam a figura do Monarca a cada crime cometido, de forma direta. Cada pena executada era uma agressão ao povo e um reforço à soberania do poder real. As injustiças e excessos cometidos nas punições eram atribuídas ao poder monárquico, 
exclusivamente. Isso descredibilizava ainda mais o Império, que no Brasil já tinha o poder fragilizado em inúmeras esferas.

Com o advento do novo regime republicano, a economia de poder foi redistribuída e desconcentrada pela humanização das penas. Um herói cívico supliciado por almejar a independência tornou-se o discurso preferido da República, cumprindo a dupla função de exaltar o regime vigente, o governo do povo como um Estado que protege e respeita seus cidadãos e desprestigiar a Monarquia, que oprimia seu povo. Tiradentes foi o elemento simbólico da superação da crueldade do antigo regime pela República humanitária.

A prisão como forma punitiva foi prevista pela primeira vez no Brasil pelo código penal de 1890. Complexidades como o regime escravista foram superadas e a implantação da ordem burguesa tornou o cenário mais favorável para a nova forma de punir. As competências do processo e execução penal passaram do rei para várias instituições, o que deu ao governo republicano características mais humanitárias ante o povo. É na nova economia de poder de punir que o estudo de Tiradentes resgata o verdadeiro sentido da reforma humanista.

\section{REFERÊNCIAS}

BATISTA, Nilo. Punidos e Mal Pagos: violência, justiça, segurança pública e direitos humanos no Brasil de hoje. Rio de Janeiro: Revan, 1990.

BECCARIA, C. Dos delitos e das penas. 3. Ed. São Paulo: Martins Fontes, 2005.

CARVALHO, J. M. A formação das almas: o imaginário da República no Brasil. São Paulo: Companhia das Letras, 1990.

DAL RI JÚNIOR, Arno. 0 Estado e seus inimigos: a repressão política na história do direito penal. Rio de Janeiro: Revan, 2006.

\section{DAL RI JÚNIOR, Arno. La storiografia giuridica brasiliana letta attraverso l'esperienza}

storiografica penale: note per la consolidazione di uma disciplina. Giuffré, 1974. Disponível em:< http://www.centropgm.unifi.it/cache/biblioteca/104/0148.pdf>. Acesso em: 10 abr. 2016.

FONSECA, M. A. Michel Foucault e o direito. São Paulo: Max Limonad, 2002, p.128.

FONSECA, Ricardo Marcelo. A cultura jurídica brasileira e a questão da codificação civil no século XIX. Revista da Faculdade de Direito UFPR. Curitiba, v. 44, p. 61-76, 2007. Disponível em: <http:// egov.ufsc.br/portal/sites/default/files/anexos/32391-39035-1-PB.pdf>. Acesso em: 10 abr. 2016

FOUCAULT, Michel. Vigiar e punir: nascimento da prisão. 41. ed. Petrópolis: Vozes, 2013. 
FURTADO, João Pinto. Uma república entre dois mundos: Inconfidência Mineira, historiografia e temporalidade. Revista Brasileira de História, v. 21, n. 42, p. 343-363, 2001. Disponível em:< http:// www.scielo.br/scielo.php?pid=S0102-01882001000300005\&script=sci_arttext\&tlng=es $>$. Acesso em: 10 abr. 2016.

KOERNER, Andrei. Punição, disciplina e pensamento penal no Brasil do século XIX. Lua Nova, v. 68, p. 205-242, 2006. Disponível em: <http://www.scielo.br/pdf/\%0D/ln/n68/a08n68.pdf>. Acesso em: 10 abr. 2016

MAXWELL, Kenneth. A devassa da devassa: a Inconfidência Mineira, Brasil-Portugal, 17501808. Rio de Janeiro: Paz e Terra, 1985.

PORTUGAL. Ordenações Filipinas - Livro V (1603). 14. ed. Rio de Janeiro : Typ. do Instituto Philomathico, 1870. Disponível em: <www2.senado.leg.br/bdsf/item/id/242733> Acesso em: 10 abr. 2016.

SALGADO, Karine. O Direito no Brasil Colônia à Luz da Inconfidência Mineira. Revista Brasileira de Estudos Políticos, v. 98, 2008, p.479-494. Disponível em : http://www.pos.direito.ufmg.br/rbep/ index.php/rbep/article/view/82/80>. Acesso em: 10 abr. 2016.

SBRICCOLI, Mario. Crimen laesae maiestatis: il problema del reato politico alle soglie della scienza penalistica moderna. Giuffrè, 1974.

TOSTO, Ricardo; LOPES, Paulo Guilherme M. 0 processo de Tiradentes. Conjur Editorial, 2006. 
1 Graduada em Direito. Mestrado em História do Direito, na Área de Concentração de Direito do Estado, pelo Programa de Pós-Graduação em Direito (PPGD) da Universidade Federal do Paraná (UFPR). laispiletti@gmail.com

2 Doutora em Direito Político e Econômico na Universidade Presbiteriana Mackenzie, com bolsa Capes/Prosuc; Professora em Direito no Centro Universitário Adventista de São Paulo.fernandacovolan@hotmail.com

\section{(). (1) (2)}

Este artigo é licenciado na modalidade acesso abertosob a Atribuição-Compartilhalgual CC BY-SA

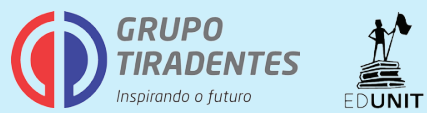

